\title{
Oral Quercetin Supplementation Lowers Plasma sICAM-1 Concentrations in Female db/db Mice
}

\author{
Silvia Wein ${ }^{1 *}$, Eva Schrader ${ }^{1,2^{*}}$, Gerald Rimbach$^{2}$, Siegfried Wolffram $^{1}$ \\ ${ }^{1}$ Institute of Animal Nutrition \& Physiology, Christian-Albrechts-University of Kiel, Kiel, Germany; ${ }^{2}$ Institute of Human Nutrition \\ and Food Science, Food Science Research Group, Christian-Albrechts-University of Kiel, Kiel, Germany. \\ Email: wein@aninut.uni-kiel.de
}

Received October $24^{\text {th }}, 2012$; revised November $27^{\text {th }}, 2012$; accepted December $18^{\text {th }}, 2012$

\begin{abstract}
Background: Flavonoids are documented for their potential anti-adipogenic, anti-inflammatory and anti-diabetic effects. Quercetin, one of the most abundant flavonoids in edible plants, was investigated for these effects in a diabetic mouse model ( $\mathrm{db} / \mathrm{db}$, leptin receptor mutation) exerting early relevant clinical signs of non-insulin dependent diabetes mellitus, such as hyperglycemia, hyperinsulinemia, hypertriglyceridemia, hypoadiponectinemia and obesity. Materials \& Methods: Female $\mathrm{db} / \mathrm{db}$ mice $(\mathrm{n}=24)$ were fed a flavonoid-poor maintenance diet without $(\mathrm{C})$ or with the addition of quercetin $(0.3 \mathrm{~g} / \mathrm{kg}$ diet, Q) or rosiglitazone $(4 \mathrm{mg} / \mathrm{kg}$ diet, TZD). Food and water were freely available during the 4 week feeding period. Thereafter, blood samples (fasted) were analyzed for glucose, insulin, triacylglycerols, non-esterified fatty acids, cholesterol, adiponectin and soluble intercellular adhesion molecule-1 (sICAM-1). Adiponectin mRNA levels were measured in adipose tissue. Furthermore, sICAM-1 release was investigated using tumor necrosis factor alpha stimulated EAhy926 cells. Results: Only TZD treatment reduced fasted plasma glucose, triacylglycerols and cholesterol and increased plasma adiponectin concentrations compared to groups $\mathrm{C}$ and Q. Adiponectin mRNA levels after quercetin treatment were not different from TZD-treatment or controls. Only quercetin treatment reduced sICAM-1 release in vitro and in vivo. Conclusions: Quercetin effectively reduced sICAM-1 release in the progressive diabetic state, revealing its anti-inflammatory potential in vivo.
\end{abstract}

Keywords: Quercetin; Inflammation; Insulin Resistance; Obesity; Adiponectin

\section{Introduction}

Obesity is associated with endocrine dysfunction of adipose tissue resulting in elevated secretion of pro-inflammatory cytokines [1], oxidative stress [2], and hypoadiponectinemia [3] contributing to the pathogenesis of insulin resistance [4]. Cytokines, such as tumor necrosis factor alpha (TNF- $\alpha$ ), induce the expression and release of adhesion molecules (ICAM-1) in different cell types [5]. In chronic inflammatory diseases, the soluble ICAM-1 (sICAM 1) occurs in the circulation and can be used as a biomarker of inflammation [6]. Adiponectin, a $30-\mathrm{kDa}$ protein, is the product of the ADIPOQ gene expressed exclusively in adipocytes [7]. Transcription of ADIPOQ is mainly regulated by the two transcription factors peroxisome proliferator-activated receptor gamma $(\mathrm{PPAR}-\gamma)$ [8] and CCAAT/enhancer binding protein $(\mathrm{C} / \mathrm{EBP} \alpha)[9]$. Whereas reactive-oxygen species and proinflammatory cytokines negatively affect adiponectin expression and secretion, PPAR- $\gamma$ agonists, $n-3$ polyun-

${ }^{*}$ First two authors contributed equally to the study. saturated fatty acids and cannabinoid-1 receptor antagonists, induce adiponectin production [10]. Adiponectin (globular and full-length) promotes insulin signalling in skeletal muscle and liver. In skeletal muscle, both circulating forms of adiponectin stimulate 5'-AMP-activated kinase (AMPK)-dependent fatty acid oxidation and glucose uptake [10]. In liver, only full-length adiponectin activates AMPK, and thus reduces gluconeogenesis and increases fatty-acid oxidation [10].

The thiazolidinedione rosiglitazone, a well established insulin-sensitizing drug and potent PPAR- $\gamma$-agonist, induces adiponectin secretion [10], confers antioxidant effects [11], induces fatty acid oxidation [12] and causes body weight gain [13]. However, drugs used for the treatment of obesity and insulin resistance in the past, including the thiazolidinedione rosiglitazone, have been associated with serious side effects (e.g. increased risk of non-fatal heart failure, associations with myocardial infarction, bone loss/fracture, and water retention) [14]. Consequently, the use of complementary and alternative medicine has increased tremendously in recent years [15]. 
Flavonoids, a group of polyphenolic secondary plant compounds, have long been recognized for their health promoting effects $[16,17]$. Data suggests that the flavonol quercetin (Figure 1) inhibits intestinal glucose transporter 2 (GLUT 2) [18], improves glucose uptake in adipocytes [19], inhibits adipocyte differentiation [19] and possesses anti-inflammatory and anti-oxidant properties $[20,21]$. In rats fed a high-fat diet, quercetin stimulated adiponectin secretion [21] and increased adiponectin mRNA concentration in adipose tissue via a PPAR- $\gamma$ independent mechanism [21]. Epidemiological studies indicate an association between flavonoid intake and a reduced risk for certain chronic diseases, including diabetes mellitus and coronary heart diseases [22]. Thus, the aim of the present study was to investigate the adiponectin-inducing, anti-inflammatory and anti-obesity effects of quercetin in an obese, insulin resistant mouse model, and to compare these effects to a well known PPAR- $\gamma$-agonist. The $\mathrm{db} / \mathrm{db}$ mouse is a well-established animal model for non-insulin dependent diabetes mellitus (NIDDM) in man, characterized by pronounced obesity already by the age of 6 weeks, accompanied by fasted hyperglycemia and hyperinsulinemia [23].

\section{Materials \& Methods}

\subsection{Animals and Diets}

Female db/db mice (BKS.Cg-m+/+Lepr $<$ db $>/ J)(n=24$, initial body weight $30.4 \pm 0.6 \mathrm{~g}$, Charles River Laboratories, Brussels, Belgium) were housed in cages with sawdust-covered solid flooring in a controlled environment $\left(22^{\circ} \mathrm{C} \pm 2^{\circ} \mathrm{C}\right.$, humidity $\left.65 \%\right)$ with a 12 -h light/dark cycle. Mice are homozygous for spontaneous mutation in the $\mathrm{db}$ gene $\left(\right.$ Lepr $\left.^{d b}\right)$ causing uncontrolled rise in blood sugar, severe depletion of pancreatic $\beta$-cells and death by 10 months of age. Animals had free access to food and tap water. During the first week, all animals were fed a flavonoid poor diet (C1000 control diet, Altromin GmbH, Lage, Germany, Table 1) without additives; thereafter animals were randomly assigned to one of the three groups and received the same flavonoid poor diet without (C) or with the addition of rosiglitazone $(4 \mathrm{mg} / \mathrm{kg}$ diet, TZD.<smiles>O=c1c(O)c(-c2ccc(O)c(O)c2)oc2cc(O)cc(O)c12</smiles>

Figure 1. Chemical structure of the flavonol quercetin.
Table 1. Crude nutrient composition of the flavonoid poor diet.

\begin{tabular}{cc}
\hline Content & Amount \\
\hline Crude protein, \% & 17.6 \\
Crude fat, \% & 5.1 \\
Crude fibre, \% & 4.1 \\
Crude ash, \% & 5.5 \\
Disaccharide, \% & 11.1 \\
Polysaccharide, \% & 47.2 \\
Dry matter, \% & 91.8 \\
Metabolizable energy, $\mathrm{MJ} / \mathrm{kg}$ & 14.6 \\
\hline
\end{tabular}

Avandia ${ }^{\circledR}$, GlaxoSmithKline, Munich, Germany) or of quercetin $(0.3 \mathrm{~g} / \mathrm{kg}$ diet, Q; quercetin-dihydrate, Carl Roth $\mathrm{GmbH}+\mathrm{Co}$. KG, Karlsruhe, Germany) for 4 weeks. Diets were prepared weekly, stored in the dark at $-18^{\circ} \mathrm{C}$ and gently thawed at room temperature just before being administered (daily at the beginning of the dark phase; removal of food residuals). Body weights were monitored weekly. After 4 weeks, blood was collected from the tail vein for glucose measurements $\left(\mathrm{HemoCue}{ }^{\circledR}\right.$ System, HemoCue GmbH, Grossostheim, Germany) and to obtain plasma samples in EDTA tubes $(2.6 \mathrm{~mL}$, Sarstedt AG \& Co., Nürnbrecht, Germany) in the 12-h fasted state at the end of the dark phase. Thereafter, animals were sacrificed under anesthesia $\left(\mathrm{CO}_{2}\right)$ by decapitation and all tissues and organs were immediately dissected, snapfrozen in liquid nitrogen and stored at $-86^{\circ} \mathrm{C}$. Fresh weight of liver and peri-uterine adipose tissue was determined before freezing. Institutional and national guidelines for the care and use of animals were followed. Animal experiments were approved by the Ministry of Agriculture, the Environment and Rural Areas of Land Schleswig-Holstein, Germany (No. V 312-72241.121-25).

\subsection{Determination of Plasma Metabolites and Hormones}

Plasma triacylglycerols (TG), non-esterified fatty acids (NEFA) and total cholesterol were quantified spectrophotometrically (Konelab 20i, Konelab Corporation, Espoo, Finnland) using commercially available kits (TG, cholesterol: Thermo Fisher Scientific GmbH, Dreieich, Germany; NEFA: WAKO Chemicals, Neuss, Germany). Plasma concentrations of insulin, adiponectin and sICAM-1 were measured by enzyme linked immuno sorbent assay (ELISA) using commercial kits (insulin: ELISA Kit, DRG Diagnostics, Germany; adiponectin: ELISA Quantikine ${ }^{\circledR}$ mouse Adiponectin/Acrp30, R\&D Systems GmbH, Wiesbaden, Germany sICAM-1: Quantikine $^{\circledR}$ mouse ELISA sICAM-1, R\&D Systems GmbH, Wiesbaden, Germany). 


\subsection{RNA Isolation and Real-Time Quantitative RT-PCR}

Frozen adipose tissue (peri-uterine) was ground in a cryo mill (A11 basic, IKA, Staufen, Germany). Total RNA was isolated from tissues according to manufacturer's (Qiagen, Hilden, Germany) protocols using the RNeasy ${ }^{\circledR}$ Lipid Tissue Mini Kit. RNA was quantified spectrophotometrically at $260 \mathrm{~nm}$ (DU 800 Spectrophotometer, Beckman Coulter GmbH, Krefeld, Germany) and RNA quality was assessed by a denaturing agarose gel electrophoresis stained with ethidium bromide.

One-step real-time quantitative RT-PCR was performed using the Rotor-Gene 6000 device (Corbett Life Science, LFT Labortechnik GmbH \& CoKG, Wasserburg/B, Germany) and Sensi-Mix PCR kits (Quantance, Berlin, Germany). mRNA concentrations of the target gene (adiponectin) were related to mRNA concentrations of the housekeeping gene $\beta$-actin. Primers (Table 2) were designed using Primer3 software (version 0.4.0, open source) and purchased from MWG (Ebersberg, Germany). Reaction parameters were: $30 \mathrm{~min}$ at $49^{\circ} \mathrm{C}$ (reverse transcription), $10 \mathrm{~min}$ at $95^{\circ} \mathrm{C}$ (hold, 3-step cycling), $15 \mathrm{~s}$ at $94^{\circ} \mathrm{C}$ (denaturation), $30 \mathrm{~s}$ at $55^{\circ} \mathrm{C}$ (annealing), and $30 \mathrm{~s}$ at $72^{\circ} \mathrm{C}$ (extension, 40 times). All measurements were performed in duplicates and efficiency of the PCR was between $90 \%$ and $100 \%$.

\subsection{Cell Culture}

EAhy926 endothelial-like cells were kindly provided by Dr. Edgell (University of North Carolina, Chapel Hill, USA) and cultured in Dulbecco's modified Eagles Medium containing glucose $(4 \mathrm{~g} / \mathrm{L})$, supplemented with Lglutamine $(2 \mathrm{mmol} / \mathrm{L})$, fetal bovine serum $(10 \%)$, penicillin $(100 \mathrm{mU} / \mathrm{mL})$ and streptomycin $(100 \mu \mathrm{g} / \mathrm{mL})$. This cell line was obtained by fusion of human umbilical vein endothelial cells (HUVEC) with the permanent human lung carcinoma cells A549 and possesses characteristics of endothelial cells 24 . Cells were grown in a humidified incubator at $37^{\circ} \mathrm{C}$ with $5 \% \mathrm{CO}_{2}$. Confluent cells were split using a trypsin/EDTA mix. sICAM-1 release in EAhy926 cells.

Table 2. Nucleotide sequences of primers and conditions used for real-time quantitative RTPCR.

\begin{tabular}{ccc}
\hline Gene & Sequence & AT ${ }^{\circ} \mathrm{C}$ Size bp \\
\hline Act $\begin{array}{l}\text { F5'-GACAGGATGCAGAAGGAGATTACT-3’ } \\
\text { R5'-TGATCCACATCTGCTGGAAGGT-3' }\end{array}$ & 55 & 142 \\
Adp $\begin{array}{l}\text { F5'-AGACCTGGCCACTTTCTCCT-3' } \\
\text { R5'-ACGTCATCTTCGGCACT-3' }\end{array}$ & 55 & 135
\end{tabular}

Act $=\beta$-actin, NC_000071.5; Adp $=$ adiponectin, NC_000082.5; AT $=$ annealing temperature; $\mathrm{F}=$ forward primer; $\mathrm{R}=$ reverse primer.
For determination of sICAM-1 in TNF- $\alpha$-stimulated endothelial cells, 200.000 EAhy926 cells/well were seeded in a twelve-well plate. After $24 \mathrm{~h}$ cultivation, the culture medium was replaced with a medium containing quercetin (25 $\mu \mathrm{mol} / \mathrm{L})$ or TZD (1 $\mu \mathrm{mol} / \mathrm{L}$, Biozol Diagnostics, Eching, Germany). This TZD concentration was proven to activate PPAR- $\gamma$ in a reporter gene assay using Dimethyl sulfoxide $(0.1 \%)$ as negative control. Quercetin and TZD concentrations tested in these cells had no adverse effects on cell viability (determined by neutral red assay). After $24 \mathrm{~h}$ of incubation, the medium was aspirated and the cells washed once with pre-warmed PBS to completely remove test substances. Subsequently, PBS was replaced and cells were stimulated for $24 \mathrm{~h}$ with 1 ng/mL human TNF- $\alpha$ (Invitrogen $\mathrm{GmbH}$, Karlsruhe, Germany). Thereafter, supernatants were collected and aliquots stored at $-80^{\circ} \mathrm{C}$ for sICAM-1 analysis. sICAM-1 concentrations of supernatants were assessed by commercial sandwich ELISA (Quantikine ${ }^{\circledR}$ Human ELISA sICAM-1/CD54, R\&D Systems GmbH, Wiesbaden, Germany). The undiluted samples were applied to a 96-well plate with immobilized monoclonal antibodies against human sICAM-1. ELISA was performed according to the manufacturer's protocol. For the determination of sICAM-1, three independent experiments in triplicate were carried out.

\subsection{Statistical Analysis}

Results are reported as means with the standard error of the mean (SEM). Statistical analysis was performed using GraphPad Prism (GraphPad Software Inc., Version 4.01, 2004, San Diego, USA). Comparisons of group means were performed by 1-way ANOVA with subsequent Tukey's Multiple Comparison Test or 2-way ANOVA with Bonferroni post tests as indicated. Significance was set at $\mathrm{P}<0.05$.

\section{Results}

\subsection{Plasma Parameter}

Four weeks of oral quercetin treatment of female $\mathrm{db} / \mathrm{db}$ mice reduced plasma sICAM-1 concentrations compared to controls (Table 3). sICAM-1 concentrations also tended $(\mathrm{P}<0.058)$ to be lower in the quercetin-treated group compared to in the TZD-treated group (Table 3). In contrast to TZD treatment, quercetin treatment did not result in reduced fasting plasma glucose, TG or cholesterol levels compared to controls (Table 3). While fasting plasma insulin concentrations were not different between treatment groups, plasma adiponectin concentrations were nearly 3-fold higher in TZD-treated mice compared to controls or quercetin treated animals (Table 3). Both TZD and quercetin treatment lowered fasting plasma NEFA concentrations compared to controls. 
Table 3. Fasting plasma parameters and liver weight of db/db mice after 28 days treatment period.

\begin{tabular}{cccc}
\hline Parameter & Control & TZD & Quercetin \\
\hline Glucose $[\mathrm{mmol} / \mathrm{L}]$ & $18.6 \pm 1.2^{\mathrm{a}}$ & $8.4 \pm 0.4^{\mathrm{b}}$ & $15.8 \pm 1.2^{\mathrm{a}}$ \\
TG $[\mathrm{mmol} / \mathrm{L}]$ & $1.3 \pm 0.06^{\mathrm{a}}$ & $1.0 \pm 0.06^{\mathrm{b}}$ & $1.3 \pm 0.07^{\mathrm{a}}$ \\
NEFA $[\mathrm{mmol} / \mathrm{L}]$ & $1.5 \pm 0.1^{\mathrm{a}}$ & $1.0 \pm 0.1^{\mathrm{b}}$ & $1.0 \pm 0.1^{\mathrm{b}}$ \\
CHOL $[\mathrm{mmol} / \mathrm{L}]$ & $5.7 \pm 0.4^{\mathrm{a}}$ & $3.6 \pm 0.3^{\mathrm{b}}$ & $5.3 \pm 0.3^{\mathrm{a}}$ \\
Insulin $[\mathrm{nmol} / \mathrm{L}]$ & $1.6 \pm 0.3$ & $2.2 \pm 0.3$ & $1.5 \pm 0.5$ \\
ACRP30 $[\mu \mathrm{g} / \mathrm{mL}]$ & $4.0 \pm 0.5^{\mathrm{a}}$ & $11.4 \pm 1.6^{\mathrm{b}}$ & $6.4 \pm 0.1^{\mathrm{a}}$ \\
sICAM-1 $[\mathrm{ng} / \mathrm{mL}]$ & $319 \pm 13^{\mathrm{a}}$ & $279 \pm 14^{\mathrm{ab}}$ & $251 \pm 13^{\mathrm{b}}$ \\
Liver $^{\mathrm{a}}[\mathrm{mg} / \mathrm{g}]$ & $6.0 \pm 0.2$ & $5.8 \pm 0.3$ & $6.0 \pm 0.3$ \\
\hline
\end{tabular}

Data are means $\pm \operatorname{SEM}(\mathrm{n}=8), 1$-way ANOVA, values bearing no common superscript differ significantly; $\mathrm{ACRP} 30$ = full weight adiponectin; $\mathrm{CHOL}=$ total cholesterol; NEFA = non-esterified fatty acids; sICAM = soluble intercellular adhesion molecule; TG $=$ triacylglycerol; TZD $=$ rosiglitazone $(0.02$ $\mathrm{g} / \mathrm{kg}$ diet, Avandia ${ }^{\circledR}$, GlaxoSmithKline, Munich, Germany). ${ }^{\mathrm{a}}$ Relative liver weight (mg tissue/g body weight).

\subsection{Body Weight, Liver and Peri-Uterine Fat Mass and Adiponectin Expression in Adipose Tissue}

In all dietary groups, animals continuously gained body mass during the feeding period (Figure 2), but after 3 and 4 weeks body weight was higher in the TZD group compared to groups C and Q (Figure 2). Quercetin and control mice did not differ with respect to body weight (Figure 2). For body weight gain, a 2-way ANOVA indicated that treatment $(17.86 \%, \mathrm{~F}=18.79, \mathrm{P}<0.0001)$, duration of treatment $(44.19 \%, \mathrm{~F}=39.21, \mathrm{P}<0.0001)$ as well as interaction $(4.8 \%, \mathrm{~F}=2.13, \mathrm{P}<0.0421)$ between treatment and the duration of treatment were significant. No differences were observed in liver weight between treatment groups (Table 3), while in the TZD-treated group peri-uterine fat mass was reduced by about $22 \%$ compared to controls and by $28 \%$ compared to quercetin treatment (Figure 2, inset).

This reduction in peri-uterine fat mass in the TZDtreated group was accompanied by higher adiponectin mRNA concentrations when compared to controls only (Figure 3).

\section{3. sICAM-1 Release in Stimulated EAhy926 Endothelial Like Cells}

The No sICAM-1 was detected in the supernatant of unstimulated EAhy926 endothelial cells. However, stimulation of EAhy926 cells with TNF- $\alpha$ for 24 hours markedly increased the release of sICAM-1. While TZD had no effect on sICAM-1 release in stimulated EAhy 926 cells, quercetin reduced the release of sICAM-1 by $37 \%$ (Figure 4).

\section{Discussion}

In the present study, we aimed to investigate potential

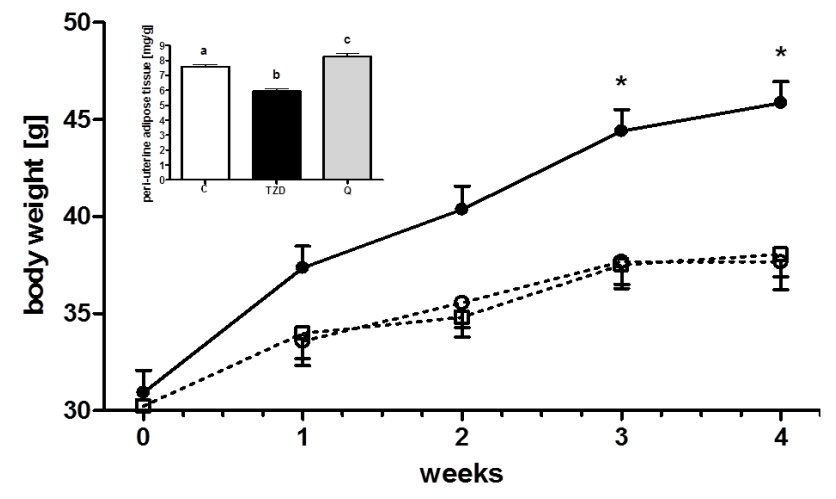

Figure 2. Body mass development of $\mathrm{db} / \mathrm{db}$ mice over 4 weeks and peri-uterine fat mass (inset) after 4 weeks of dietary treatment without (control, $\mathrm{C}$-O-) or with rosiglitazone $\left(4 \mathrm{mg} / \mathrm{kg}\right.$ diet, Avandia ${ }^{\circledR}$, GlaxoSmithKline, Munich, Germany, TZD -O-) or quercetin (0.3 g/kg diet, $Q-\square-)$. Data are means and SEM $(\mathrm{n}=8), 2$-way ANOVA * $\mathrm{P}<0.05$ compared to controls or quercetin treatment, inset: 1-way ANOVA, bars bearing no common superscript differ significantly, $\mathrm{P}<\mathbf{0 . 0 0 0 1}$.

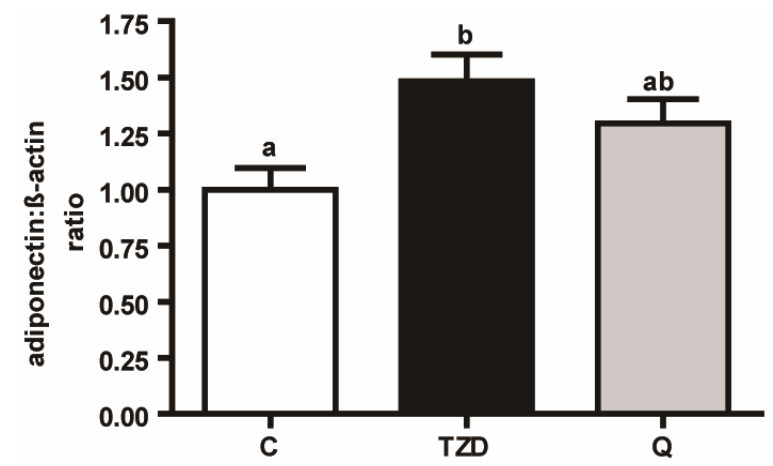

Figure 3. Relative adiponectin mRNA-concentrations in peri-uterine adipose tissue after 4 weeks of dietary treatment without (C) or with rosiglitazone (4 mg/ $\mathrm{kg}$ diet, Avandia $^{\circledR}$, GlaxoSmithKline, Munich, Germany, TZD) or quercetin $(0.3 \mathrm{~g} / \mathrm{kg}$ diet, $Q)$. Data are means and SEM $(\mathrm{n}=8)$, 1-way ANOVA, bars bearing no common superscript differ significantly, $P=0.0145$.

anti-inflammatory, anti-adipogenic and glucose lowering effects of orally supplemented quercetin in a diabetes mouse model ( $\mathrm{db} / \mathrm{db}$ mice). The $\mathrm{db} / \mathrm{db}$ mouse has been extensively used to study NIDDM [25] and is characterized by early signs of NIDDM, e.g. hyperglycemia, hyperinsulinemia, hypertriglyceridemia, hypoadiponectinemia and obesity [23]. In vitro studies in 3T3-L1 preadipocytes have indicated anti-adipogenic effects of the flavonol quercetin, suggesting inhibition of differentiation [26,27] and TG accumulation [27]. Oral quercetin supplementation has also been shown to reduce visceral adipose tissue in $\mathrm{C} 56 \mathrm{BL} / 6 \mathrm{~J}$ mice and obese Zucker rats fed a high-fat/high-sucrose diet for 20 [28] and 10 weeks [29], respectively. However, in the present study, 4 weeks of oral quercetin supplementation in $\mathrm{db} / \mathrm{db}$ mice 


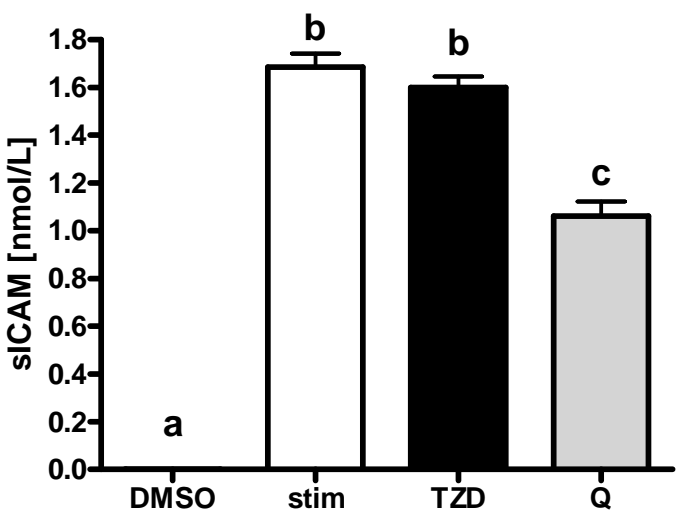

Figure 4. Effect of quercetin on sICAM-1 release in tumor necrosis factor alpha (TNF- $\alpha$ ) stimulated EAhy926 cells. EAhy926 cells were incubated $(24 \mathrm{~h})$ with either dimethyl sulphoxide (0.1\%, DMSO), rosiglitazone (1 $\mu \mathrm{mol} / \mathrm{L}$, Biozol Diagnostics, Eching, Germany, TZD) or quercetin (25 $\mu \mathrm{mol} / \mathrm{L}, \mathrm{Q})$. Pre-incubation was followed by stimulation with TNF- $\alpha(1 \mathrm{ng} / \mathrm{mL})$ except for DMSO (serving as negative control). Values are means with SEM of three independent experiments performed in triplicate, 1-way ANOVA, bars bearing no common superscript differ significantly, $\mathrm{P}<$ 0.0001 .

had no effect on body weight and rather increased periuterine adipose tissue. Although these results are in contrast to the aforementioned studies, data from further experiments using quercetin as an oral supplement support our findings. Indeed, previous studies in rats fed a high-fat diet [21], in healthy mice [30] and in streptozotocin-induced diabetic rats $[31,32]$ revealed no impact of quercetin on body weight gain. Additionally a 2-year study in healthy male and female $\mathrm{F} 344 / \mathrm{N}$ rats demonstrated that quercetin had no effect on body weight unless it was given at a concentration of $4 \%$ in the diet for at least one year [33]. Differences between studies are likely due to the quercetin dose, duration of treatment, species used and choice of model. We have chosen the $\mathrm{db} / \mathrm{db}$ mouse as a model of diabetes because it reliably reflects the development of insulin resistance towards progressive $\beta$-cell failure with hyperglycemia as found in human NIDDM. Based on the results from the present study in $\mathrm{db} / \mathrm{db}$ mice and previous studies in other animal models of obesity [28,29], we conclude that the effects of quercetin are not anti-adipogenic. Rosiglitazone, a member of the thiazolidinediones and a well-established insulin-sensitizing drug, is known to increase body weight [34]. Thus anti-diabetic effects of rosiglitazone are not based on anti-adipogenic properties. In the present study, rosiglitazone induced an expected increase in body weight in $\mathrm{db} / \mathrm{db}$ mice compared to controls. However, the body weight increase was accompanied by higher circulating adiponectin concentrations and by smaller peri-uterine fat pad sizes, suggesting that rosiglitazone treatment might induce a change in adipose tissue distribution. Redistri- bution of adipose tissue has been observed in rodents as well as in humans [35]. Present data suggests that the type of adipose tissue has an impact on adipokine secretion and insulin sensitivity and thus might be more relevant than total body weight or total body fat mass. Although oral quercetin supplementation may exert antidiabetic effects by increasing plasma adiponectin concentrations in high fat diet-fed rats $[21,36]$ and mice [28] the same dose was ineffective in inducing adiponectin mRNA and plasma concentrations in $\mathrm{db} / \mathrm{db}$ mice after 4 weeks of treatment.

Obesity and insulin resistance both have a mild chronic inflammation in common, often accompanied by elevated TNF- $\alpha$ secretion from adipose tissue. Although controversial, TZD treatment has been shown to exert antiinflammatory and cardiovascular protective effects due to the suppression of cytokine release [37]. In the present $\mathrm{db} / \mathrm{db}$ mouse study, in contrast to TZD-treatment, quercetin-treatment clearly inhibited sICAM-1 release compared to controls, which might be due to inhibition of TNF- $\alpha$ or nuclear factor-kappa B (NFkB)-signaling [38]. Data from this study suggests that anti-inflammatory effects are, at least in part, due to the inhibition TNF- $\alpha$ signaling. We demonstrate herein that in vitro quercetin $(25 \mu \mathrm{mol} / \mathrm{L})$ inhibited TNF- $\alpha$-induced sICAM- 1 release by $37 \%$ in EAhy 926 cells and by $22 \%$ in $\mathrm{db} / \mathrm{db}$ mice fed a diet containing $0.3 \mathrm{~g}$ quercetin $/ \mathrm{kg}$ for 4 weeks. In the present study, TZD, which previously failed to reduce TNF- $\alpha$ mRNA concentrations in white adipose tissue of $\mathrm{db} / \mathrm{db}$ mice $[39,40]$, neither inhibited sICAM-1 release in vitro nor in vivo. These results suggest that the effects of TZD are not based on TNF- $\alpha$-inhibition.

In summary, oral quercetin effectively reduced sICAM1 release in vitro and in $\mathrm{db} / \mathrm{db}$ mice and thus might exert anti-inflammatory effects also in the progressive diabetic state. Feeding a flavonoid poor maintenance diet containing $0.3 \mathrm{~g}$ quercetin $/ \mathrm{kg}$ diet over 4 weeks, however, did not exert glucose-lowering or adiponectin-inducing effects in $\mathrm{db} / \mathrm{db}$ mice.

\section{Acknowledgements}

Authors thank Wiebke Kühl for excellent technical assistance.

\section{REFERENCES}

[1] V. Vachharajani and D. N. Granger, "Adipose Tissue: A Motor for the Inflammation Associated with Obesity," IUBMB Life, Vol. 61, No. 4, 2009, pp. 424-430. doi:10.1002/iub.169

[2] H. K. Vincent and A. G. Taylor, "Biomarkers and Potential Mechanisms of Obesity-Induced Oxidant Stress in Humans," International Journal of Obesity, Vol. 30, No. 3, 2006, pp. 400-418. doi:10.1038/sj.ijo.0803177 
[3] J. Spranger, A. Kroke, M. Mohlig, M. M. Bergmann, M. Ristow, H. Boeing and A. F. Pfeiffer, "Adiponectin and Protection against Type 2 Diabetes Mellitus," Lancet, Vol. 361, No. 9353, 2003, pp. 226-228. doi:10.1016/S0140-6736(03)12255-6

[4] P. Dandona, A. Aljada and A. Bandyopadhyay, "Inflammation: The Link between Insulin Resistance, Obesity and Diabetes," Trends in Immunology, Vol. 25, No. 1, 2004, pp. 4-7. doi:10.1016/i.it.2003.10.013

[5] J. Constans and C. Conri, "Circulating Markers of Endothelial Function in Cardiovascular Disease," Clinica Chimica Acta, Vol. 368, No. 1-2, 2006, pp. 33-47. doi:10.1016/j.cca.2005.12.030

[6] A. J. H. Gearing, I. Hemingway, R. Pigott, J. Hughes, A. J. Rees and S. J. Cashman, "Soluble Forms of Vascular Adhesion Molecules, E-Selectin, ICAM-1, and VCAM-1Pathological Significance," Annals of the New York Academy of Sciences, Vol. 667, No. 1, 1992, pp. 324-331. doi:10.1111/j.1749-6632.1992.tb51633.x

[7] E. Hu, P. Liang and B. M. Spiegelman, "AdipoQ Is a Novel Adipose-Specific Gene Dysregulated in Obesity," Journal of Biological Chemistry, Vol. 271, No. 18, 1996, pp. 10697-10703. doi:10.1074/jbc.271.18.10697

[8] N. Maeda, M. Takahashi, T. Funahashi, S. Kihara, H. Nishizawa, K. Kishida, H. Nagaretani, M. Matsuda, R. Komuro, N. Ouchi, H. Kuriyama, K. Hotta, T. Nakamura, I. Shimomura and Y. Matsuzawa, "PPARgamma Ligands Increase Expression and Plasma Concentrations of Adiponectin, an Adipose-Derived Protein," Diabetes, Vol. 50, No. 9, 2001, pp. 2094-2099. doi:10.2337/diabetes.50.9.2094

[9] L. P. Qiao, P. S. MacLean, J. Schaack, D. J. Orlicky, C. Darimont, M. Pagliassotti, J. E. Friedman and J. H. Shao, "C/EBPa Regulates Human Adiponectin Gene Transcription through an Intronic Enhancer," Diabetes, Vol. 54, No. 6, 2005, pp. 1744-1754. doi:10.2337/diabetes.54.6.1744

[10] M. Guerre-Millo, “Adiponectin: An Update," Diabetes \& Metabolism, Vol. 34, No. 1, 2008, pp. 12-18. doi:10.1016/j.diabet.2007.08.002

[11] Z. Bagi, A. Koller and G. Kaley, "PPAR\{gamma\} Activation, by Reducing Oxidative Stress, Increases NO Bioavailability in Coronary Arterioles of Mice with Type 2 Diabetes," AJP-Heart and Circulatory Physiology, Vol. 286, No. 2, 2004, pp. H742-H748.

[12] C. R. Benton, G. P. Holloway, S. E. Campbell, Y. Yoshida, N. N. Tandon, J. F. C. Glatz, J. J. J. F. Luiken, L. L. Spriet and A. Bonen, "Rosiglitazone Increases Fatty Acid Oxidation and Fatty Acid Translocase (FAT/CD36) but Not Carnitine Palmitoyltransferase I in Rat Muscle Mitochondria," Journal of Physiology-London, Vol. 586, No. 6, 2008, pp. 1755-1766. doi:10.1113/jphysiol.2007.146563

[13] J. Wilding, "Thiazolidinediones, Insulin Resistance and Obesity: Finding a Balance," International Journal of Clinical Practice, Vol. 60, No. 10, 2006, pp. 1272-1280. doi:10.1111/j.1742-1241.2006.01128.x

[14] R. M. Viner, Y. Hsia, T. Tomsic and I. C. K. Wong, "Efficacy and Safety of Anti-Obesity Drugs in Children and Adolescents: Systematic Review and Meta-Analysis,"
Obesity Reviews, Vol. 11, No. 8, 2010, pp. 593-602. doi:10.1111/j.1467-789X.2009.00651.x

[15] J. Kennedy, "Herb and Supplement Use in the US Adult Population," Clinical Therapeutics, Vol. 27, No. 11, 2005, pp. 1847-1858. doi:10.1016/j.clinthera.2005.11.004

[16] E. Middleton, C. Kandaswami and T. C. Theoharides, "The Effects of Plant Flavonoids on Mammalian Cells: Implications for Inflammation, Heart Disease, and Cancer," Pharmacological Reviews, Vol. 52, No. 4, 2000, pp. 673-751.

[17] G. Williamson and C. Manach,. "Bioavailability and Bioefficacy of Polyphenols in Humans. II. Review of 93 Intervention Studies," American Journal of Clinical Nutrition, Vol. 81, Suppl. 1, 2005, pp. 243S-255S.

[18] O. Kwon, P. Eck, S. Chen, C. P. Corpe, J. H. Lee, M. Kruhlak and M. Levine, "Inhibition of the Intestinal Glucose Transporter GLUT2 by Flavonoids," FASEB Journal, Vol. 21, No. 2, 2007, pp. 366-377. doi:10.1096/fj.06-6620com

[19] X. K. Fang, J. Gao and D. N. Zhu, "Kaempferol and Quercetin Isolated from Euonymus alatus Improve Glucose Uptake of 3T3-L1 Cells without Adipogenesis Activity," Life Sciences, Vol. 82, No. 11-12, 2008, pp. 615622. doi:10.1016/j.1fs.2007.12.021

[20] Y. Kumazawa, K. Kawaguchi and H. Takimoto, "Immunomodulating Effects of Flavonoids on Acute and Chronic Inflammatory Responses Caused by Tumor Necrosis Factor Alpha," Current Pharmaceutical Design, Vol. 12, No. 32, 2006, pp. 4271-4279. doi: $10.2174 / 138161206778743565$

[21] S. Wein, N. Behm, R. K. Petersen, K. Kristiansen and S. Wolffram, "Quercetin Enhances Adiponectin Secretion by a PPAR-Gamma Independent Mechanism," European Journal of Pharmaceutical Sciences, Vol. 41, No. 1, 2010, pp. 16-22. doi:10.1016/j.ejps.2010.05.004

[22] B. A. Graf, P. E. Milbury and J. B. Blumberg, "Flavonols, Flavones, Flavanones, and Human Health: Epidemiological Evidence," Journal of Medicinal Food, Vol. 8, No. 3, 2005, pp. 281-290. doi:10.1089/jmf.2005.8.281

[23] P. R. Johnson, M. R. C. Greenwood, B. A. Horwitz and J. S. Stern, "Animal-Models of Obesity - Genetic-Aspects," Annual Review of Nutrition, Vol. 11, 1991, pp. 325-353. doi:10.1146/annurev.nu.11.070191.001545

[24] C. J. Edgell, C. C. McDonald and J. B. Graham, "Permanent Cell Line Expressing Human Factor VIII-Related Antigen Established by Hybridization," Proceedings of the National Academy of Sciences of the USA, Vol. 80, No. 12, 1983, pp. 3734-3737. doi:10.1073/pnas.80.12.3734

[25] K. Srinivasan and P. Ramarao, "Animal Models in Type 2 Diabetes Research: An Overview," Indian Journal of Medical Research, Vol. 125, No. 3, 2007, pp. 451-472.

[26] J. Ahn, H. Lee, S. Kim, J. Park and T. Ha, "The AntiObesity Effect of Quercetin Is Mediated by the AMPK and MAPK Signaling Pathways," Biochemical and Biophysical Research Communications, Vol. 373, No. 4, 2008, pp. 545-549. doi:10.1016/j.bbrc.2008.06.077

[27] P. J. Chien, Y. C. Chen, S. C. Lu and F. Sheu, "Dietary 
Flavonoids Suppress Adipogenesis in 3T3-L1 Preadipocytes," Journal of Food and Drug Analysis, Vol. 13, No. 2, 2005, pp. 168-175.

[28] M. Kobori, S. Masumoto, Y. Akimoto and H. Oike, "Chronic Dietary Intake of Quercetin Alleviates Hepatic Fat Accumulation Associated with Consumption of a Western-Style Diet in C57/BL6J Mice," Molecular Nutrition \& Food Research, Vol. 55, No. 4, 2011, pp. 530-540. doi:10.1002/mnfr.201000392

[29] L. Rivera, R. Moron, M. Sanchez, A. Zarzuelo and M. Galisteo, "Quercetin Ameliorates Metabolic Syndrome and Improves the Inflammatory Status in Obese Zucker Rats," Obesity, Vol. 16, No. 9, 2008, pp. 2081-2087. doi:10.1038/oby.2008.315

[30] J. Barrenetxe, P. Aranguren, A. Grijalba, J. M. MartinezPenuela, F. Marzo and E. Urdaneta, "Effect of Dietary Quercetin and Sphingomyelin on Intestinal Nutrient Absorption and Animal Growth," British Journal of Nutrition, Vol. 95, No. 3, 2006, pp. 455-461. doi:10.1079/BJN20051651

[31] T. Mahesh and V. P. Menon, "Quercetin Allievates Oxidative Stress in Streptozotocin-Induced Diabetic Rats," Phytotherapy Research, Vol. 18, No. 2, 2004, pp. 123127. doi: $10.1002 /$ ptr. 1374

[32] A. K. Shetty, R. Rashmi, M. G. R Rajan, K. Sambaia and P. V. Salimath, "Antidiabetic Influence of Quercetin in Streptozotocin-Induced Diabetic Rats," Nutrition Research, Vol. 24, No. 5, 2004, pp. 373-381.

[33] J. K. Dunnick and J. R. Hailey, "Toxicity and Carcinogenicity Studies of Quercetin, a Natural Component of Foods," Fundamental and Applied Toxicology, Vol. 19, No. 3, 1992, pp. 423-431. doi:10.1016/0272-0590(92)90181-G

[34] J. Wilding, "Thiazolidinediones, Insulin Resistance and Obesity: Finding a Balance," International Journal of
Clinical Practice, Vol. 60, No. 10, 2006, pp. 1272-1280. doi:10.1111/j.1742-1241.2006.01128.x

[35] P. Tontonoz and B. M. Spiegelman, "Fat and Beyond: The Diverse Biology of PPAR Gamma," Annual Review of Biochemistry, Vol. 77, 2008, pp. 289-312. doi:10.1146/annurev.biochem.77.061307.091829

[36] O. Y. Kim, S. M. Lee, H. Do, J. Moon, K. H. Lee, Y. J. Cha and M. J. Shin, "Influence of Quercetin-Rich Onion Peel Extracts on Adipokine Expression in the Visceral Adipose Tissue of Rats," Phytotherapy Research, Vol. 26, No. 3, 2011, pp. 432-437.

[37] A. Hammarstedt, C. X. Andersson, S. V. Rotter and U. Smith, "The Effect of PPARgamma Ligands on the Adipose Tissue in Insulin Resistance," Prostaglandins, Leukotrienes and Essential Fatty Acids, Vol. 73, No. 1, 2005, pp. 65-75. doi:10.1016/j.plefa.2005.04.008

[38] M. Comalada, D. Camuesco, S. Sierra, I. Ballester, J. Xaus, J. Galvez and A. Zarzuelo, "In Vivo Quercitrin Anti-Inflammatory Effect Involves Release of Quercetin, Which Inhibits Inflammation through Down-Regulation of the NF-kappaB Pathway," European Journal of Immunology, Vol. 35, No. 2, 2005, pp. 584-592. doi:10.1002/eji.200425778

[39] G. B. Moore, H. Chapman, J. C. Holder, C. A. Lister, V. Piercy, S. A. Smith and J. C. Clapham, "Differential Regulation of Adipocytokine mRNAs by Rosiglitazone in $\mathrm{db} / \mathrm{db}$ Mice," Biochemical and Biophysical Research Communications, Vol. 286, No. 4, 2001, pp. 735-741. doi:10.1006/bbrc.2001.5460

[40] A. Suzuki, T. Yasuno, H. Kojo, J. Hirosumi, S. Mutoh and Y. Notsu, "Alteration in Expression Profiles of a Series of Diabetes-Related Genes in $\mathrm{db} / \mathrm{db}$ Mice Following Treatment with Thiazolidinediones," Japanese Journal of Pharmacology, Vol. 84, No. 2, 2000, pp. 113-123. doi:10.1254/iip.84.113 